\title{
Biogeochemical consequences of winter flooding in brook valleys
}

\author{
Victor Beumer · Geert van Wirdum . \\ Boudewijn Beltman · Jasper Griffioen • \\ Jos T. A. Verhoeven
}

Received: 5 December 2006/ Accepted: 5 July 2007/Published online: 9 August 2007

(C) Springer Science+Business Media B.V. 2007

\begin{abstract}
Climatic change has great impacts on stream catchments and their ecology. Expectations are that more extreme climate events will result in undesired flooding in stream catchments. In the Netherlands, former floodplains with a history of agricultural use are put into use again as flooding areas for the purpose of water retention. This study focuses on the effects of winter flooding on various plant site conditions in the soil, such as redox, nutrient, $\mathrm{pH}$, and base status. We compared the effects on groundwater- and rainwater-dominated floodplains. Water chemistry $\left(\mathrm{pH}, \mathrm{EC}, \mathrm{HCO}_{3}, \mathrm{SO}_{4}\right.$, $\mathrm{Cl}, \mathrm{Ca}, \mathrm{Mg}, \mathrm{Na}, \mathrm{K}, \mathrm{p}_{\mathrm{CO}_{2}}, \mathrm{NO}_{3}, \mathrm{NH}_{4}$, and $\mathrm{PO}_{4}$ ) and soil nutrients (Total $\mathrm{N}$ and $\mathrm{P}$, and bio-available $\mathrm{P}$ ) were monitored for one year, including a 3-4 month period with winter flooding. In both floodplains no direct effect of the flood-water chemistry was detected in the pore water, because the soil pores had become saturated with groundwater or rainwater, respectively, just before flooding, flood-water did not penetrate the soil. We found that the increase in $\mathrm{pH}$ and ammonium concentration in the rainwater flood-
\end{abstract}

V. Beumer $(\varangle) \cdot$ B. Beltman · J. T. A. Verhoeven Landscape Ecology, Institute of Environmental Biology, Utrecht University, P.O.Box 80084, 3508 TB Utrecht, The Netherlands

e-mail: v.beumer@bio.uu.nl

V. Beumer · G. van Wirdum · J. Griffioen TNO Netherlands Geological Survey, Utrecht, The Netherlands plain were due to changes in redox status, resulting from the completely water-filled state of the soil pores during the flooding event. Furthermore, we noticed an increase in soil nutrient contents and a shift in plant species composition in the rainwater floodplain: the vegetation included more plant species characteristic for N-richness. Finally, we conclude that winter flooding has more drastic effects on biogeochemical conditions and vegetation composition in the atmotrophic conditions characteristic for low-order subcatchments than in lithotrophic conditions in the larger, higher-order subcatchments of the stream basin.

Keywords Flooding $\cdot$ Streams $\cdot$ Natural vegetation · $\mathrm{pH} \cdot$ Pore water chemistry $\cdot$ Soil nutrients

\section{Introduction}

The Intergovernmental Panel for Climatic Change (Watson et al. 2001; McCarthy et al. 2001) has predicted drastic effects of climatic change in the next 100 years. Climatic change affects river catchments and their associated wetlands throughout the world by increasing extreme precipitation events (Hartig et al. 1997; Mortsch 1998; Winter 2000; Burkett and Kusler 2000; Johnson et al. 2005). In the Dutch stream catchments increased frequency and duration of floodings are expected during winter as a result of the larger amounts of precipitation and the 
more frequent extreme events (Klein Tank et al. 2006). Western and central European countries have already reported an increase in the number and duration of winter flood events (Bronstert 1995; Black 1995; Black and Werritty 1997). Dutch water managers try to coordinate such floodings by appointing areas for controlled flood-water detention. In the eastern Netherlands, which generally consists of sandy soils above sea level, lowland stream catchments are a characteristic landscape feature. Surplus precipitation partly infiltrates in porous sediments, while the remaining part is discharged by rivers and brooks. In the past, many of these streams have been modified to improve drainage for agriculture. However, natural discharge and infiltration are expected to no longer suffice in the near future, resulting in undesired inundation of agricultural and residential areas. To alleviate this problem, former floodplains of rivers and brooks as well as other areas in brook valleys are assigned and made suitable for flood-water detention in winter (Ministry of Housing, Spatial Planning and the Environment 2001). A brook valley can be defined as a valley of a small river or stream, characterized by a wide variety of hydro-chemical influences along the valley slope resulting in gradients of vegetation (Grootjans 1985).

Until 1900, floodplains in the lower parts of brook valleys in the Netherlands became flooded naturally in winter, while in summer the soils usually were saturated with groundwater (Everts and De Vries 1991; Wassink 1999). A variety of semi-natural vegetation types on these floodplains occurred because of their specific hydrological regime and the variety of chemical water types present (Everts and de Vries 1991). In the twentieth century almost all of these semi-natural brook valleys were drained to use them for more intensive agriculture. Brooks and rivers were canalized to prevent flooding and to ensure rapid water discharge. The effects of lowering groundwater levels or fertilization (e.g., increased mineralization and soil nutrient availability) of the soil have been investigated (Grootjans et al. 2002; Kemmers et al. 2003) and the importance of restoration of the hydrological regime in protecting the species-rich vegetation was emphasized. Hence, the restoration of floodplains for the purpose of water management and flood control may be in the interest of the restoration and conservation of nature at the same time.
However, the opportunities for conservation will vary depending upon various properties of the previously modified brook valleys, as well as the origin of the local groundwater and the floodwaters. The high nutrient richness of soils and river water, and a lowered groundwater level provide a significantly different environment for plants than did the soils of the original intact brook valley. In respect of their natural vegetation, Dutch brook valleys roughly fall into two groups, based on their groundwater level (Stortelder 1998). Either upward groundwater flow locally reaches the soil surface, or it is absent or never reaches the upper 20 or $30 \mathrm{~cm}$ of the soil. The soils of the first group are dominated by a "lithotrophic" water type, chemically similar to calcareous groundwater, while in the second group an "atmotrophic" water type, chemically similar to rainwater (Van Wirdum 1991), is expected to infiltrate and dominate in the upper soil layers. Both situations may well occur in a gradient within the same river catchment or brook valley, with atmotrophic conditions prevailing in the lower-order streams and lithotrophic conditions more downstream. River water from the stream may become more important with increased winter flooding in both valley types.

An effective strategy to estimate the effects of renewed winter flooding on the present vegetation is to specifically identify changes in plant site conditions. Flood events have three major effects: depletion of oxygen in the soil pores, change in pore water chemistry because of flood-water penetration, and increased soil nutrient content by sedimentation (Blom et al. 1990; Visser et al. 2003; Kozerski 2003; Walls et al. 2005). These major effects may cause a variety of biogeochemical changes on their turn. Important is the soil oxygen depletion, because it is known to dictate processes, such as denitrification, methanogenesis, the reduction of manganese, iron, and sulfate, resulting in a lowering of the soil redox potential (Gambrell 1991). Furthermore, reduction processes increase the levels of phytotoxins, such as sulfides (Caraco et al. 1989; Lamers et al. 1998). Alterations in $\mathrm{pH}$ and redox potential will change the bio-availability of nutrients in the soil (Stumm and Morgan 1981; Troelstra et al. 1990; Reddy et al. 1999). Generally, soils in floodplains are loaded with nutrients and cations during winter flooding (Wassen 1995). With 
the later objective to make predictions of the response of the vegetation, we will focus in this article on the effects of winter flooding on nutrient availability, $\mathrm{pH}$, base status, and redox status of the soil as main plant site conditions.

Specific objectives in this study were to distinguish between the effects of flooding on the wetness of sites and the effects of flood-water on pore water chemistry. By exploring lithotrophic as well as atmotrophic floodplains we wanted to compare their opportunities for restoration of plant site conditions in relation to winter flooding. Therefore our major research questions were: To what extent are plant site conditions affected by winter flooding and can we find differences between floodplains dominated by lithotrophic and atmotrophic pore water chemistry? How is the floodplain nutrient status affected in both types? How are the $\mathrm{pH}$ and base status affected? To find an answer to these questions we selected two detention areas assigned for winter flooding in brook valleys: one had a high groundwater table throughout the year, while the other had a low groundwater table during periods without flooding. In both floodplains we laid out a transect of three plots along an elevational gradient and monitored these for water table, pore water chemistry, soil nutrient availability, and plant species composition.

\section{Material and methods}

Site descriptions

This investigation was carried out in two brook valleys in the Netherlands, the Beerze in the province of Noord-Brabant and the Snoeyinksbeek in the province of Overijssel (Fig. 1). The Netherlands has a temperate climate with rainfall in every season; the mean annual precipitation is about $800 \mathrm{~mm}$ with a net precipitation surplus of $200-240 \mathrm{~mm}$ and the mean annual temperature is $9-10^{\circ} \mathrm{C}$ (KNMI database 2006). In the valley of the Beerze we studied a floodplain (Logtse Baan) of 43 ha in size with a history of agricultural use. In $2000,15-30 \mathrm{~cm}$ of the floodplain top soil was removed and it was endiked to allow winter flooding. Since then, it remained inundated up to 4 months each winter. The studied area along the Snoeyinksbeek is only 3 ha and has a history of agricultural use as well. The top soil was removed in 2001 and since then annual winter flood events lasting up to 2 months have occurred.

The Beerze catchment is complex. The river originates in Belgium, some $45 \mathrm{~km} \mathrm{~S}$ of the Logtse Baan at the border of the Tertiary Kempen Plateau. It then flows through the relatively narrow, Pleistocene Mid-Brabant ridge catchment system, to re-enter the
Fig. 1 The stream catchments and the study sites of the Beerze (B) and Snoeyinksbeek (S) and their location in The Netherlands, with research plots, stream directions and stream width in winter

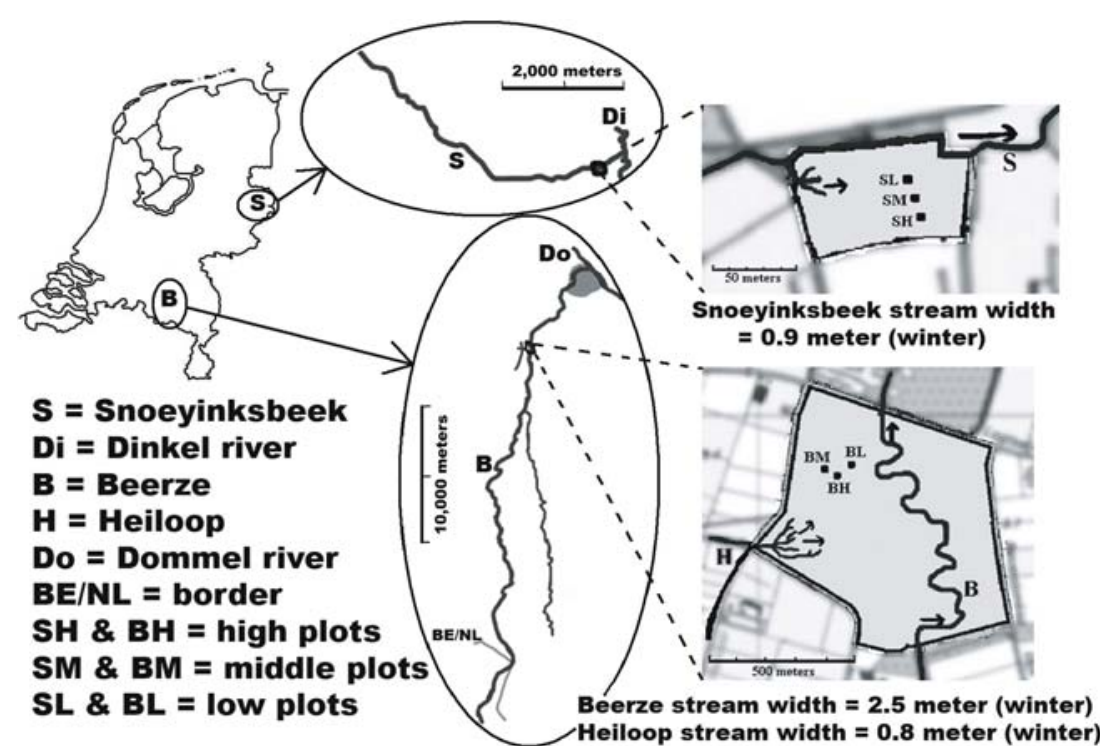


lower part of the large Kempens Plateau catchment system south of our floodplain. Here, it must be considered a second order stream. The floodplain $\left(51^{\circ} 32^{\prime} 31.00^{\prime \prime} \mathrm{N}\right.$ and $\left.5^{\circ} 15^{\prime} 45.15^{\prime \prime} \mathrm{E}\right)$ lies at $+10 \mathrm{~m}$ NAP (Dutch Ordnance Level). The main deposit underneath the shallow floodplain deposits, is a 5-15 m thick Late Pleistocene layer of periglacial sands and loams, comprising the phreatic aquifer with a main infiltration area $15 \mathrm{~km}$ south-east of our floodplain (Stuurman et al. 2000). This aquifer is hydrologically semi-continuous with the underlying, very thick and extensive main regional aquifer consisting of Early to Mid Pleistocene and Tertiary deposits (Engelen et al. 1989). Hence, the Beerze flood-water may comprise groundwater contributions of mixed origin. Apart from the Beerze, the small stream (first order) Heiloop, which hardly contains water in summer, does contribute to winter flooding of the Logtse Baan floodplain.

The Snoeyinksbeek is a first order stream in the shallow Twente catchment. It has its source at the Enschede pushed moraine $6 \mathrm{~km}$ west of the valley part now assigned for flooding, joining the Dinkel river $1 \mathrm{~km}$ to the east. The floodplain $\left(52^{\circ} 16^{\prime} 57.60^{\prime \prime}\right.$ $\mathrm{N}$ and $7^{\circ} 01^{\prime} 03.34^{\prime \prime}$ E) lies at $+32 \mathrm{~m}$ NAP. The top $4 \mathrm{~m}$ are fluvioglacial fine sands of the Middle Pleistocene overlying $2 \mathrm{~m}$ of sands and gravels on top of a $14 \mathrm{~m}$ thick aquitard of ground moraine and glacial till. Groundwater maps and models indicate that the local groundwater is derived from rather recent rainfall (De Louw 2006; DINO 2006).
Three research plots $(2 \times 2 \mathrm{~m})$ have been laid out on an elevational gradient on both floodplains, coded: $\mathrm{BH}$ (Beerze High $=+8 \mathrm{~cm}$, Fig. 2), BM $($ Middle $=0 \mathrm{~cm})$ and $\mathrm{BL}($ Low $=-23 \mathrm{~cm})$; and $\mathrm{SH}$ (Snoeyinksbeek High $=+16 \mathrm{~cm}$, Fig. 5), SM $($ Middle $=0 \mathrm{~cm})$ and SL $($ low $=-6 \mathrm{~cm})$, respectively. At the Beerze floodplain the vegetation in plot BH was dominated by Mentha aquatica, Juncus effusus and Carex acuta (total cover 100\%), in plot BM by Lythrum salicaria, Eleocharis palustris and E. acicularis (total cover 95\%) and in plot BL only some Alisma plantago-aquatica plants were found. Plot BH had a sandy peat top layer, while plots BM and BL had plain gray sand. The vegetation at the Snoeyinksbeek floodplain covered 35, 50 and $60 \%$ in plots $\mathrm{SH}, \mathrm{SM}$ and $\mathrm{SL}$ respectively. Plot $\mathrm{SH}$ was mainly covered by liverworts (Marchantia polymorpha), while in plot SM Trifolium repens, Juncus effusus and J. conglomeratus dominated; Alopecurus geniculatus, Ranunculus repens and Plantago major were dominant in plot SL.

\section{Sampling}

Sampling was carried out from December 2003 to July 2004 on the floodplain of the Beerze and from July 2004 to January 2005 on the floodplain of the Snoeyinksbeek. Plot BM in the Beerze floodplain and the lowest point in the Snoeyinksbeek floodplain were equipped with a piezometer (diameter $2.5 \mathrm{~cm}$ and filter depth at $120 \mathrm{~cm}$ ) containing a pressure data
Fig. 2 Water table fluctuations and elevation (right side) of plots in the floodplain of the Beerze. Arrows indicate soil and water sampling. The water table is expressed in centimetres above or below soil surface of Plot BM

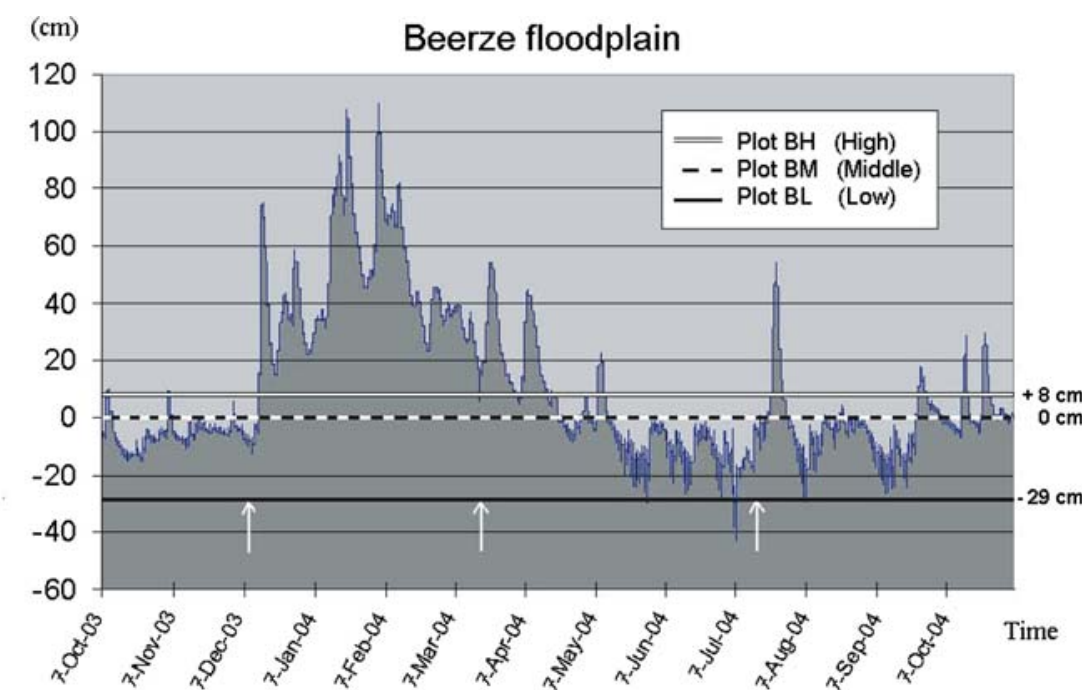


logger (Diver, Van Essen Instruments, Delft, the Netherlands) to monitor water table with 30 minutes intervals. In the piezometers of the remaining plots water depth was measured manually at sampling days. For the Beerze soil and pore water samples were collected in December 2003 (just before the start of flooding), March 2004 (during flooding) and July 2004 (no flooding). Snoeyinksbeek was sampled in July 2004 (no flooding), November 2004 (just before the start of flooding) and January 2005 (during flooding). Brook water was sampled just before flooding. Note, however, that in fact plot BL remained flooded all the time, whereas plot $\mathrm{SH}$ was hardly flooded at all. Soil samples for organic matter content, total nitrogen and total phosphorus analysis were collected in November 2004 and January 2005 in both areas. In each research plot, 5 soil samples were collected at each of three depths: 0-10 cm, 10-20 cm and 50-60 cm below surface. The soil samples were taken with an Edelman auger and put in airtight polyethylene bags to minimize contact with air. Pore water samples were collected with Rhizons (SMS$10 \mathrm{~cm}$, Eijkelkamp Agrisearch Equipment, Giesbeek, the Netherlands) each sampling day at 0-10 $\mathrm{cm}$ below soil surface. Surface water was sampled in glass bottles with exclusion of air. In the field, soil and pore water samples were stored in a cool box. Soil samples were stored overnight in a refrigerator at $3^{\circ} \mathrm{C}$ until chemical analysis. Water samples were prepared in the lab directly after arrival at the end of a sampling day and stored at $-19^{\circ} \mathrm{C}$ until further analysis.

\section{Soil and water analysis}

The $\mathrm{pH}$ and Electrical Conductivity (E.C.) of the water samples were measured at the end of a sampling day. The water samples were analyzed with a SKALAR continuous flow analyzer for: $\mathrm{Ca}$, $\mathrm{Mg}, \mathrm{K}, \mathrm{Na}, \mathrm{HCO}_{3}, \mathrm{Cl}, \mathrm{SO}_{4}, \mathrm{NO}_{3}$ (actually nitrate plus nitrite), $\mathrm{NH}_{4}$, and $\mathrm{PO}_{4}$. The soil samples were analyzed for bio-available $\mathrm{P}$, total $\mathrm{P}$, total $\mathrm{N}$, and organic matter. Bio-available $\mathrm{P}$ was determined according to the Bray-P-2 method (Bray and Kurtz 1945) using ammonium fluoride and hydrochloric acid. The concentration of phosphate in the supernatants was determined colorimetrically upon the formation of a phosphomolybdenum-blue complex (Houba et al. 1995). Total nitrogen and total phosphorus were determined by acid digestion with sulfuric acid and selenium oxide (Houba et al. 1995). The supernatant was analyzed for phosphorus and nitrogen on a SKALAR continuous flow analyzer. Dry soil samples were heated for $4 \mathrm{~h}$ at $550^{\circ} \mathrm{C}$, the percentage of weight loss was measured and estimated as organic matter by loss on ignition. Calculation of the charge balance and EC with the analytical results revealed several discrepancies, which were repeated in different batches. No obvious explanation for these discrepancies was found, however the perusal of individual subsamples, multi-component similarity coefficients and statistical tests renders our conclusions unsensitive to errors in individual analytical results.

\section{Data analysis}

Water chemistry was visualized with Maucha diagrams (Maucha 1932) and rTh-rLi diagrams with the computer program MAION (Van Wirdum 1991). rTh-rLi diagrams visualize each sample's chemical similarity to three end-members in the water cycle, i.e., calcareous groundwater (lithotrophic), rainwater (atmotrophic) and seawater (thalassotrophic) (Van Wirdum 1991). These three end-members, for which the MAION program uses fixed benchmark samples, play a key role in natural land and water systems. The partial $\mathrm{CO}_{2}$ pressure $\left(\mathrm{p}_{\mathrm{CO}_{2}}\right)$ was calculated with the computer program PHREEQC for Windows, which uses a hydrogeochemical transport model PHREEQC-2 (Parkhurst and Appelo 1999). The vegetation surveys were used to calculate mean Ellenberg indicator values per research plot for the years 2004 and 2005 (Ellenberg 1979). Water and soil chemistry data were statistically analyzed with three-way ANOVA, two-way ANOVA and ANOVA using SPSS 11.5 (SPSS Inc., Illinois, Chicago, USA).

\section{Results}

Water regime Beerze

\section{Surface water}

The local water regime in the Beerze is characterized by a long-term winter flood and flood peaks of short duration in other seasons (Fig. 2). The main flooding event started in December and ended April-May. 
Two short peaks occurred in October and November, before the main flooding event. After the main flooding event, there were several peaks in May, August, and October. The main flooding reached up to $140 \mathrm{~cm}$ above the low plot $\mathrm{BL}$ and $100 \mathrm{~cm}$ above the high plot $\mathrm{BH}$. Plot $\mathrm{BH}$ was flooded during the main flooding event, interrupted by two very short retractions in March, while Plot BM had standing water during the flooding event continuously. The low plot remained under water during the entire period. The flood-water originated from the Heiloop and Beerze streams. Figure 3 shows Maucha diagrams within the rTh-rLi diagram of the surface water samples at the Beerze floodplain, at the beginning of a flooding event and after 5 weeks of flooding. The initial similarity of the flood-water chemistry to water from the Heiloop suggests that the local flooding started from this stream. However, after 5 weeks, the flood-water resembled a mixture of Beerze water and Heiloop water.

\section{Pore water}

The top soil layer $(0-10 \mathrm{~cm})$ remained permanently under water in Plot BL (Fig. 2). Just before flood arrival (December) and in summer (July) the top soil

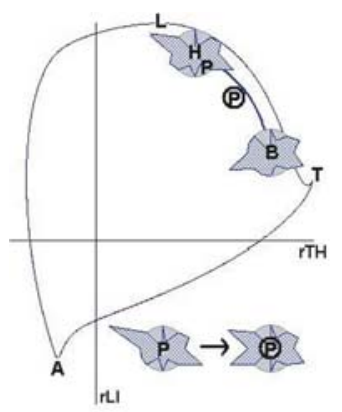

Beerze

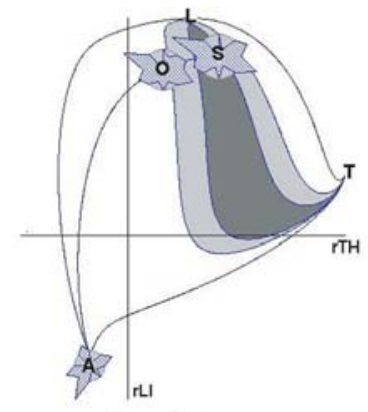

Snoeyinksbeek

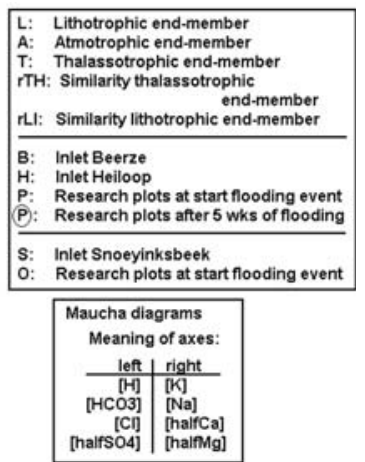

diagram, a mixing line between $\mathrm{S}$ and $\mathrm{A}$ is plotted, and areas are highlighted which represent all mixtures with more than $80 \%$ (dark-gray) and $60 \%$ (light-gray) of volume of water of the Snoeyinksbeek (S)
Fig. 3 Representation of the surface water chemistry in the floodplains along the Beerze and the Snoeyinksbeek. Maucha diagrams of surface water samples are plotted within the rTHrLI diagrams (Van Wirdum 1991). In the Beerze diagram, a mixing line is plotted between $\mathrm{H}$ and B. In the Snoeyinksbeek

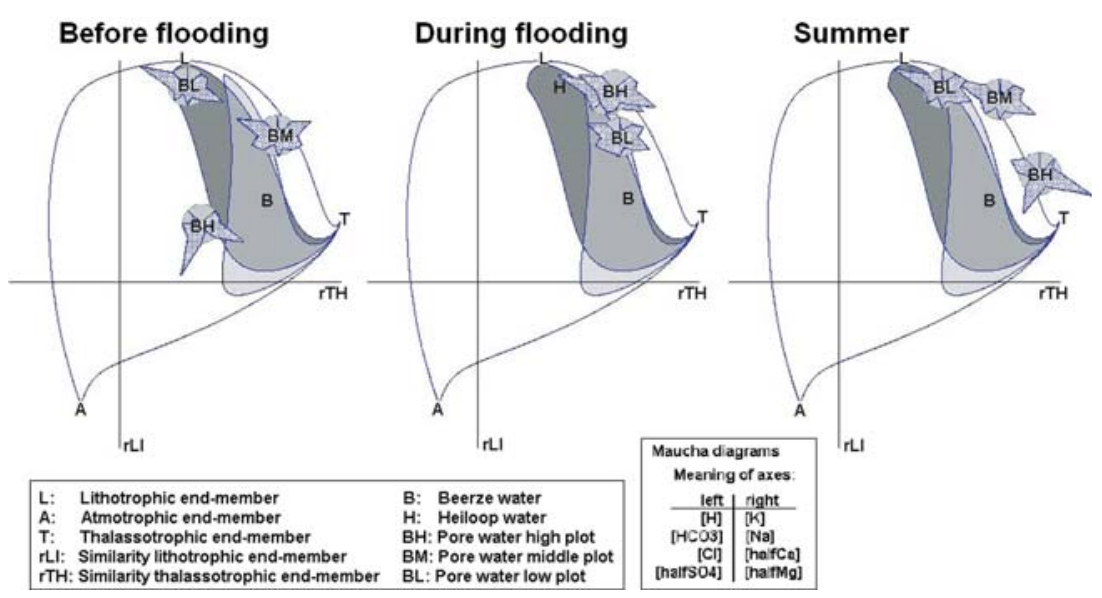

Fig. 4 Representation of the soil pore water chemistry (0$10 \mathrm{~cm}$ ) of the floodplain along the Beerze with Maucha diagrams within rTH-rLI diagrams. Plots $\mathrm{BH}, \mathrm{BM}$ and $\mathrm{BL}$ are plotted just before flooding, during flooding and after flooding, i.e., in summer. The highlighted areas represent all possible samples with more than $70 \%$ volume of water of the Heiloop (dark-gray) and the Beerze (light-gray). Note: BM during flooding is hidden behind $\mathrm{BH}$ 
layer in Plot BH was unsaturated, while it was partly water-saturated in Plot BM. Figure 4 visualizes the pore water chemistry in the top soil layers of the research plots. Table 1 summarizes all pore water chemistry measurements and the results of two-way ANOVA's with elevational gradient and time as fixed factors. The elevational gradient was reflected significantly in all pore water characteristics, except for the concentration of $\mathrm{NO}_{3}$ (Table 1). Only eight out of 14 characteristics showed significant temporal changes; the concentrations of $\mathrm{Ca}, \mathrm{HCO}_{3}, \mathrm{Na}, \mathrm{NH}_{4}$, $\mathrm{NO}_{3}$ and $\mathrm{p}_{\mathrm{CO}_{2}}$ are not significantly affected by time (Table 1).

The pore water samples of the three plots appeared in different positions within the rLi-rTh diagrams before flooding, but during flooding they clustered in a position between the lithotrophic endmember and Beerze water (Fig. 4). Plot BH started out in a position far away from the lithotrophic end member due to a relatively high $\mathrm{SO}_{4}$ concentration, whereas BL started close to Heiloop water, very near the lithotrophic end member, and BM started in between Heiloop water and Beerze water. During flooding, Plot BL became more similar to Beerze water, whereas Plots $\mathrm{BH}$ and $\mathrm{BM}$ rather moved towards the lithotrophic end-member. Plot $\mathrm{BH}$ seemed to be influenced by rainwater just before flooding, while its closer similarity to the thalassotrophic end-member in the summer and its high EC in particular suggests the influence of evaporation. However, $\mathrm{Cl}$ remained low during summer. The position of Plot BM in the rTh-rLi diagrams did not change much; it moved a little in the direction of the lithotrophic end-member during flooding. As the Maucha diagrams of this plot show, this coincides with an increased importance of $\mathrm{HCO}_{3}$ and $\mathrm{Ca}$ due to a decrease in $\mathrm{SO}_{4}$ and $\mathrm{Cl}$ in particular (Fig. 4). In Plot $\mathrm{BH}$, no chemical influence of either water of the Heiloop or the Beerze was found in the pore water chemistry, but due to variation between individual subsamples such influence can not be excluded either. Its pore water stands out due to a high proportional concentration of $\mathrm{SO}_{4}$ just before flooding and after flooding in summer. Altogether, the results of the pore water chemistry showed that probably only Plot BL was significantly influenced by the flood-water chemistry, but the effects were relatively small. Plot $\mathrm{BH}$ and $\mathrm{BM}$ are not influenced by the flood-water chemistry directly: during flood- ing they were more related to the lithotrophic end-member.

Water regime Snoeyinksbeek

\section{Surface water}

Figure 5 shows the fluctuations of the surface water level at the floodplain of the Snoeyinksbeek during and after the flood event in winter and in spring. The main flood event started in November and ended in March. In the summer prior to the main flood event there were no significant flood events. Plot SH only experienced three short flooding peaks, while Plot SM and Plot SL remained below water throughout the main flood event. The plots had a maximum water depth of $20 \mathrm{~cm}$. The origin of the flood-water was mainly water of the Snoeyinksbeek which has a chemical composition showing a substantial contribution of rainwater (Fig. 3). The Maucha diagrams show that the flood-water on top of the plots had the same chemical composition as water of the Snoeyinksbeek, though further diluted with rainwater.

\section{Pore water}

The rTh-rLi diagrams and Maucha diagrams (Fig. 6) indicate that all pore water samples are localized on the atmotrophic side of the diagram and that pore water was not influenced much by the chemistry of the flood-water. Rather than converging towards one end member during flooding, as the samples from the Beerze floodplain did (Fig. 4), the pore water samples from the Snoeyinksbeek detention area spread more widely between the lithotrophic and the atmotrophic end-members during flooding (Fig. 6). Plot SL had more similarity with the lithotrophic end-member than Plots $\mathrm{SH}$ and $\mathrm{SM}$, reflecting the gradient in water-saturation of the soil before flooding. Plot SL changed position only slightly within the rLi-rTh diagrams, which is underlined by the Maucha diagrams and by the pore water chemistry summarized in Table 2. This suggests that flood-water hardly penetrated the soil in the low part of the floodplain. During flooding, some dilution of the pore water with atmotrophic water occurred. This may be due to rain showers at the start of the flooding period (15.1 mm prior to sampling, KNMI database 2006). In fact, Plot SH was hardly flooded (Fig. 5), so 


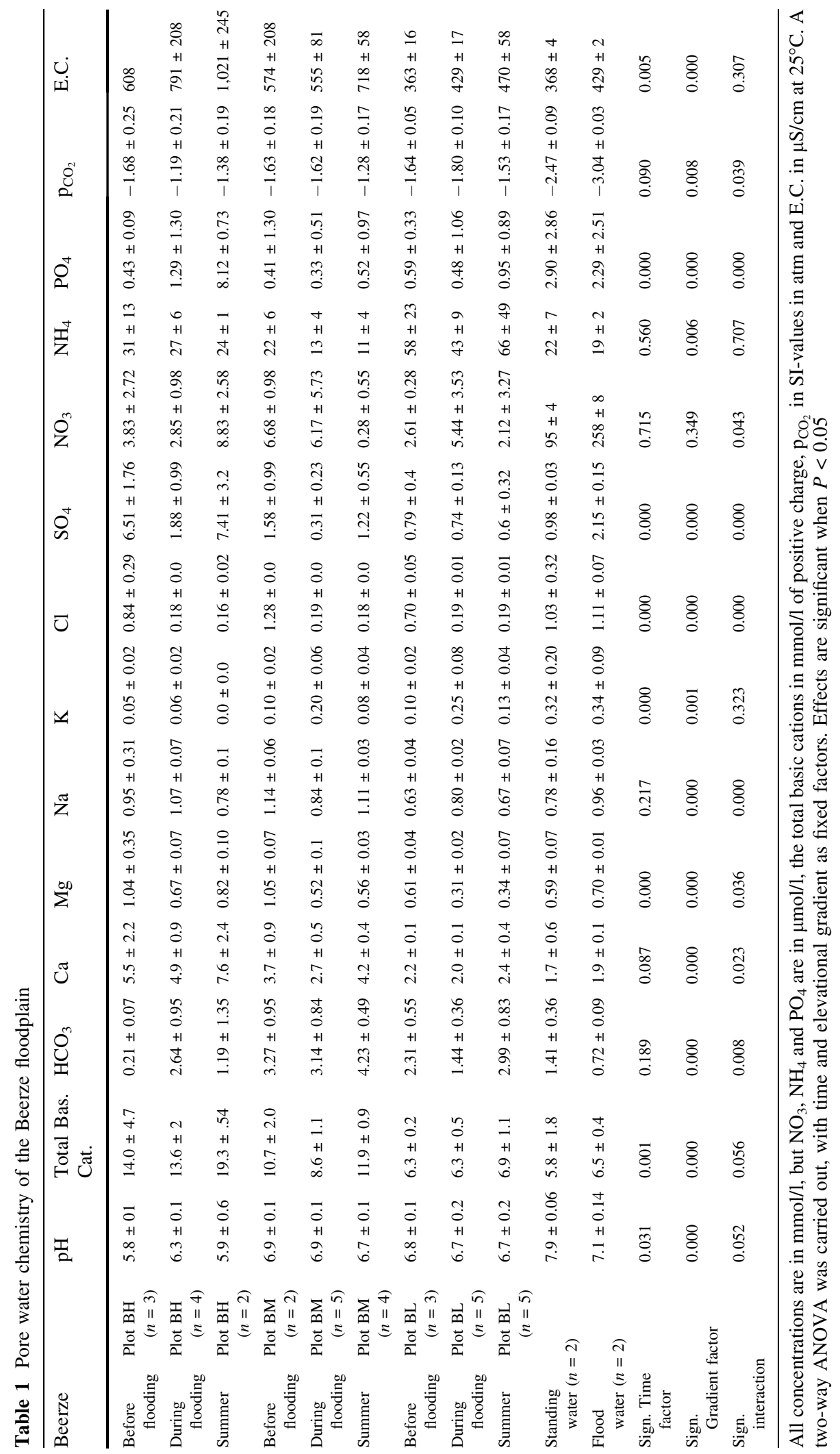


Fig. 5 Water table fluctuations and elevation (right side) of plots in the floodplain of the

Snoeyinksbeek. Arrows indicate soil and water sampling. The water table is expressed in centimetres above or below soil surface of Plot SM

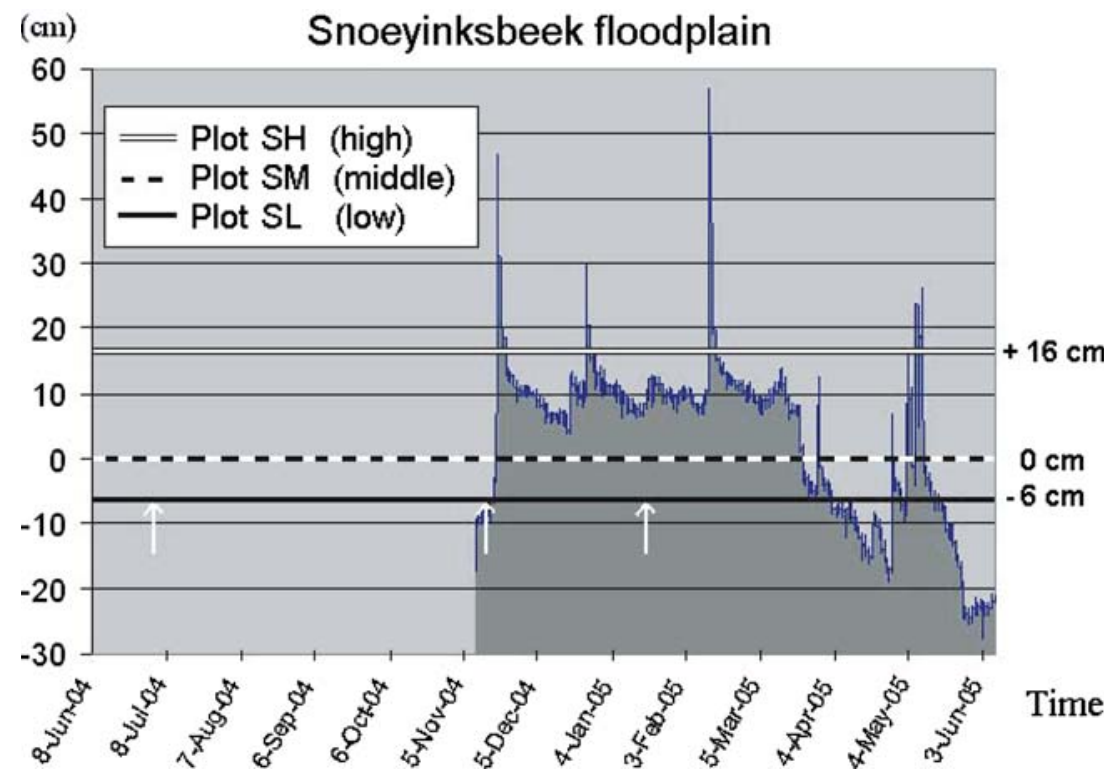

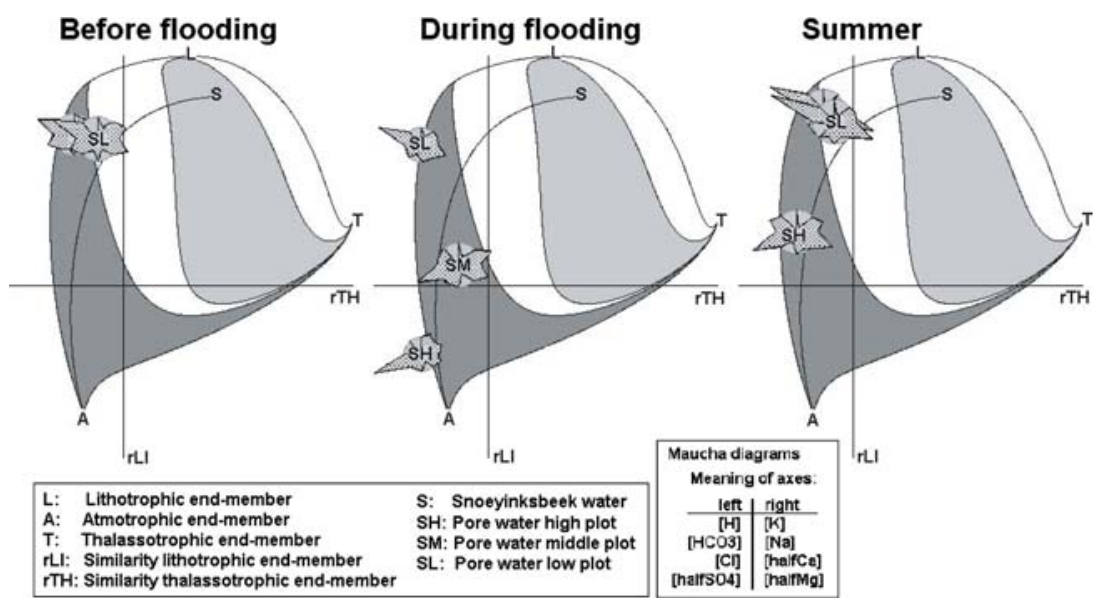

Fig. 6 Representation of the soil pore water chemistry (0$10 \mathrm{~cm}$ ) of the floodplain along the Snoeyinksbeek with Maucha diagrams within the rTH-rLI diagrams. Plots SH, SM and SL are plotted just before flooding, during flooding and after flooding, i.e., in summer. The highlighted areas represent all possible samples with more than $90 \%$ volume of the

precipitation could infiltrate and mix with the pore water. In summer, Plots SM and SL were rather similar. Time significantly affected 10 out of 14 pore water characteristics, while elevational gradient only affected six out of 14 (two-way ANOVA, Table 2). Pore water nutrients $\left(\mathrm{NO}_{3}, \mathrm{NH}_{4}\right.$, and $\left.\mathrm{PO}_{4}\right), \mathrm{SO}_{4}, \mathrm{pH}$, and $\mathrm{Ca}$ were significantly affected by time, while not by the elevational gradient. Flooding led to atmotrophic end-member (dark-gray) and $60 \%$ volume of water of the Snoeyinksbeek (light-gray). A mixing line of Snoeyinksbeek water and the atmotrophic end-member is plotted. Note: SH is missing before flooding, SM before flooding and in summer is hidden behind SL

significant increases of the $\mathrm{pH}$ and of ammonium concentrations of the pore water.

Considering all water chemistry data together, Table 3 shows the results of a three-way ANOVA test. All variables measured to represent pore water chemistry, except for $\mathrm{K}, \mathrm{NO}_{3}$, and $\mathrm{NH}_{4}$, were significantly different between the Beerze and Snoeyinksbeek areas (Table 3: all $P<0.0005$ ). The overall 


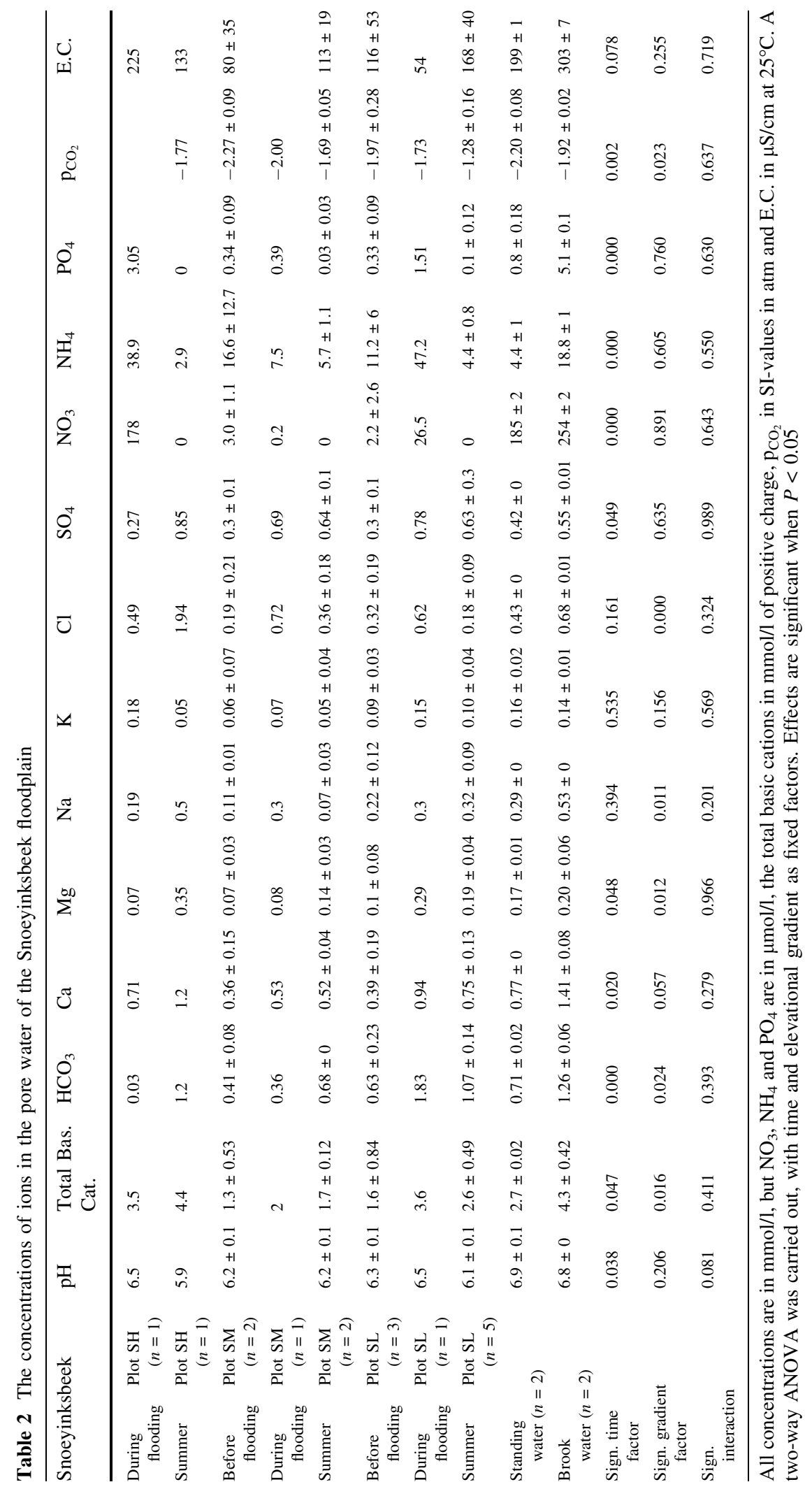


Table 3 The results of a three-way ANOVA test with pore water concentrations of the Beerze and Snoeyinksbeek floodplain

\begin{tabular}{|c|c|c|c|c|c|c|c|c|c|c|c|c|c|c|}
\hline $\begin{array}{l}\text { Three-way ANOVA } \\
(P<0.05)\end{array}$ & $\mathrm{pH}$ & $\begin{array}{l}\text { Total Bas. } \\
\text { Cat. }\end{array}$ & $\mathrm{HCO}_{3}$ & $\mathrm{Ca}$ & $\mathrm{Mg}$ & $\mathrm{Na}$ & $\mathrm{K}$ & $\mathrm{Cl}$ & $\mathrm{SO}_{4}$ & $\mathrm{NO}_{3}$ & $\mathrm{NH}_{4}$ & $\mathrm{PO}_{4}$ & $\mathrm{p}_{\mathrm{CO}_{2}}$ & E.C. \\
\hline Sign. area & 0.000 & 0.000 & 0.000 & 0.000 & 0.000 & 0.000 & 0.115 & 0.000 & 0.000 & 0.204 & 0.129 & 0.000 & 0.002 & 0.000 \\
\hline Sign. time & 0.004 & 0.026 & 0.050 & 0.005 & 0.001 & 0.274 & 0.011 & 0.000 & 0.000 & 0.000 & 0.301 & 0.000 & 0.000 & 0.001 \\
\hline Sign. elevation & 0.000 & 0.000 & 0.022 & 0.000 & 0.000 & 0.009 & 0.000 & 0.000 & 0.000 & 0.793 & 0.047 & 0.108 & 0.380 & 0.002 \\
\hline Sign. A*T & 0.213 & 0.577 & 0.024 & 0.633 & 0.000 & 0.929 & 0.295 & 0.000 & 0.659 & 0.000 & 0.060 & 0.132 & 0.046 & 0.469 \\
\hline Sign. A*E & 0.035 & 0.000 & 0.003 & 0.000 & 0.000 & 0.000 & 0.727 & 0.000 & 0.000 & 0.185 & 0.031 & 0.000 & 0.007 & 0.000 \\
\hline Sign. T*E & 0.025 & 0.017 & 0.001 & 0.004 & 0.147 & 0.000 & 0.264 & 0.000 & 0.000 & 0.016 & 0.657 & 0.000 & 0.062 & 0.217 \\
\hline Sign. A*T*E & 0.117 & 0.656 & 0.727 & 0.624 & 0.120 & 0.440 & 0.935 & 0.000 & 0.879 & 0.318 & 0.639 & 0.771 & 0.271 & 0.731 \\
\hline
\end{tabular}

Fixed factors are area (Beerze or Snoeyinksbeek), time (before, during and in summer) and elevational gradient (high, middle and low plots). Effects and interactions are significant if $P<0.05$

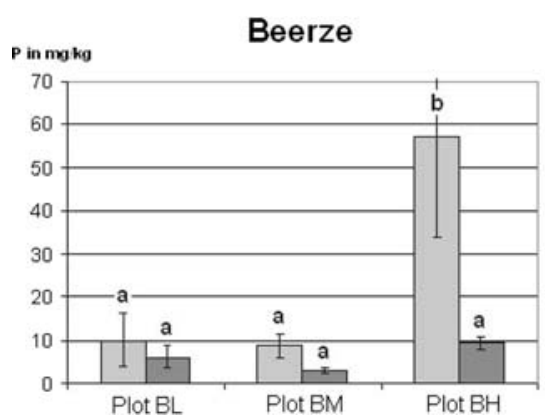

Fig. 7 Bio-available $\mathrm{P}$ in the top soil layer of the floodplains along the Beerze and the Snoeyinksbeek. The research plots were investigated along an elevational gradient and sampled before (light bars) and after (dark bars) a flooding event.

effect of both the elevational gradient and the time effect was significant for 11 out of 14 variables. Elevational gradient was not significant for $\mathrm{PO}_{4}$ and $\mathrm{NO}_{3}$, where time did have a significant effect on it. Both nutrients increased in the pore water during flooding. $\mathrm{HCO}_{3}$ and $\mathrm{Na}$ showed significant elevational effects, while time did not have a significant effect on them. In summary, considering the two different areas together, time as well as the elevational gradient appear very important for the pore water chemistry. However, the results for the separate floodplains, indicate that either the elevational gradient or time is dominant in single sites.

Soil nutrients in Beerze and Snoeyinksbeek

\section{Bio-available phosphate}

Figure 7 shows the bio-available $\mathrm{P}$ (BAP) in the top soil layer $(0-10 \mathrm{~cm})$ of the floodplains along the

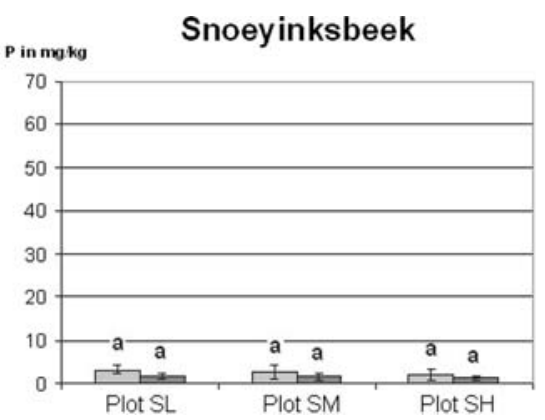

Values are shown in means $\pm \mathrm{SD}$, and followed by the same letter when not significantly different within one graph (Tukey's HSD)

Beerze and the Snoeyinksbeek. BAP was generally higher in the Beerze than in the Snoeyinksbeek floodplain and it is clearly shown that in all plots the contents of BAP were higher just before flooding than during flooding (two-way ANOVA, time effect significant, Table 4).

\section{Organic matter, total $N$ and total $P$}

Figure 8 shows the total $\mathrm{P}(\mathrm{TP})$, total $\mathrm{N}(\mathrm{TN})$, and organic matter $(\mathrm{OM})$ contents in the soils down to $60 \mathrm{~cm}$ depth for both floodplains (Plots $\mathrm{BM}$ and $\mathrm{SM})$. Plot $\mathrm{BM}$ is characterized by the influence of groundwater and the presence of an unsaturated soil before and after the main flooding event. The OM in the top soil layer of Plot BM before flooding is relatively high $(6.4 \%)$ and lower in the layers below (1.4\%). The $\mathrm{TP}$ and $\mathrm{TN}$ in the Beerze floodplain showed the same depth profile as the OM. The higher concentrations in the top soil layer $(0-10 \mathrm{~cm})$ 
Table 4 Two-way ANOVA of the bio-available P, total P, total $\mathrm{N}$ and organic matter contents in the floodplains along the Beerze and the Snoeyinksbeek, with elevational gradient (Bio$\mathrm{P})$, depth (TN, TP and OM) and time as fixed factors

\begin{tabular}{|c|c|c|c|c|c|c|c|}
\hline \multirow[t]{2}{*}{ Variable } & \multirow[t]{2}{*}{ Factor } & \multicolumn{3}{|c|}{ Beerze } & \multicolumn{3}{|c|}{ Snoeyinksbeek } \\
\hline & & df & $F$ & Sign. & df & $F$ & Sign. \\
\hline \multirow[t]{3}{*}{ Bio-P } & Time & 2 & 28.4 & 0.000 & 1 & 7.6 & 0.012 \\
\hline & Elevation & 1 & 39.4 & 0.000 & 2 & 1.6 & 0.232 \\
\hline & $\mathrm{T}^{*} \mathrm{E}$ & 2 & 19.1 & 0.000 & 2 & 0.2 & 0.799 \\
\hline \multirow[t]{3}{*}{ Total N } & Time & 1 & 2.1 & 0.158 & 1 & 37.3 & 0.000 \\
\hline & Depth & 2 & 3.8 & 0.037 & 2 & 20.6 & 0.000 \\
\hline & $\mathrm{T} * \mathrm{D}$ & 2 & 2.6 & 0.096 & 2 & 9.4 & 0.002 \\
\hline \multirow[t]{3}{*}{ Total P } & Time & 1 & 7.9 & 0.012 & 1 & 34.0 & 0.000 \\
\hline & Depth & 2 & 3.4 & 0.059 & 2 & 5.3 & 0.014 \\
\hline & $\mathrm{T} * \mathrm{D}$ & 1 & 5.5 & 0.031 & 2 & 8.2 & 0.002 \\
\hline \multirow[t]{3}{*}{ Organic matter } & Time & 1 & 9.1 & 0.006 & 1 & 68.6 & 0.000 \\
\hline & Depth & 2 & 8.0 & 0.002 & 2 & 29.8 & 0.000 \\
\hline & $\mathrm{T} * \mathrm{D}$ & 2 & 5.0 & 0.015 & 2 & 15.4 & 0.000 \\
\hline
\end{tabular}

disappeared after the start of flooding, although the change was not significant for TN (Table 4). Plot $\mathrm{SM}$ in the Snoeyinksbeek floodplain was characterized by atmotrophic characteristics of the pore water prior to flooding. The initial values for TP, TN, and $\mathrm{OM}$ in the top soil layer were much lower than in the Beerze floodplain (Fig. 8). Accordingly, just before flooding there was not a distinct depth profile of TP, TN, and $\mathrm{OM}$ as there was in the Beerze floodplain. During flooding, however, a significant increase in TN, TP, and OM down to a depth of $20 \mathrm{~cm}$ (Fig. 8), created a depth gradient. Both time and depth effects, as well as the interaction between them were significant (Table 4).

\section{Vegetation responses}

Table 5 shows the mean Ellenberg indicator values for the plant species of the research plots along the Snoeyinksbeek and the Beerze. The relatively small number of plant species in the plots that were found in both years (Table 5) indicates that the species composition was changing. The Ellenberg indicator values showed changes, but their standard deviation was rather large. The N-richness indicator values show an increase in time for both floodplains, where the increase at the Snoeyinksbeek floodplain was much larger and significant when tested with two- way ANOVA with year and elevational gradient as fixed factors $(F=6.3$ and $P=0.014)$. None of the other differences in Ellenberg values between 2004 and 2005 were significant, but the differences might still indicate trends. The moisture indicator values suggest drier conditions along the Snoeyinksbeek than along the Beerze. The vegetation at the Beerze floodplain indicates very wet conditions. At the Snoeyinksbeek site the vegetation indicates less wet conditions. The acidity values indicate that the Snoeyinksbeek floodplain was slightly more acidic than the Beerze floodplain in 2005. Furthermore, the vegetation indicated that the Snoeyinksbeek soil became less acidic.

\section{Discussion}

This study was designed to investigate the effects of a (re)introduction of winter flooding on plant site conditions in floodplains along streams. We compared the effects on floodplains characterized by lithotrophic and atmotrophic pore water chemistry. In both situations we observed that the flood-water did not penetrate into the soil, because of soil pore saturation prior to the flooding by groundwater or rainwater. However, in the atmotrophic floodplain changes in pore water chemistry (increase of $\mathrm{pH}$ and ammonium concentration) are likely to be the effect of lower redox potentials resulting from flooding. The response of soil nutrient content to the flooding was opposite in the two floodplains: in the lithotrophic floodplain we observed a loss of soil nutrients after flooding, while in the atmotrophic floodplain we observed a gain of soil nutrients. These changes in the atmotrophic floodplain occurred simultaneously with a change of plant species composition; plant species characteristic for more eutrophic conditions became established, while in the lithotrophic floodplain, we did not see changes in plant species composition. The implications of these results are that winter flooding in Dutch brook valleys will have a greater effect on plant site conditions and plant species composition in a brook valley with floods created by rain accumulation than in a valley flooded by groundwater or surface water.

We observed that a winter flooding event had significant effects on plant site conditions, i.e., $\mathrm{pH}$ and base status, macroionic composition and nutrient concentrations. These effects might have been caused 
Fig. 8 Total $\mathrm{P}$, total $\mathrm{N}$ and organic matter contents of the soils of Plots BM and $\mathrm{SM}$ in the floodplains along the Beerze and the Snoeyinksbeek before (light bars) and after flooding (dark bars) at three depths. The values are shown as means \pm SD and followed by the same letter when not significantly different within one graph (Tukey's HSD)
Beerze floodplain
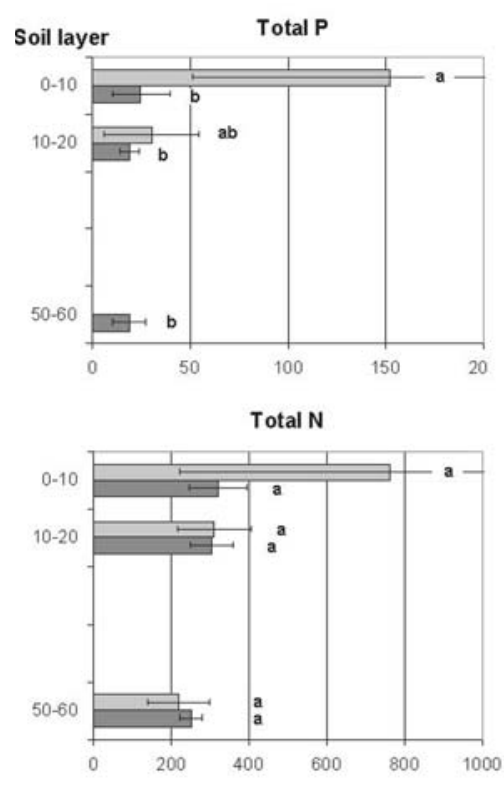

Organic Matter

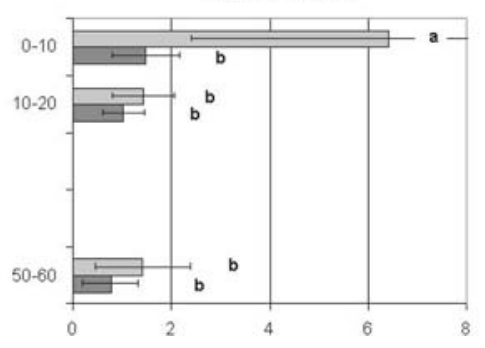

Snoeyinksbeek floodplain
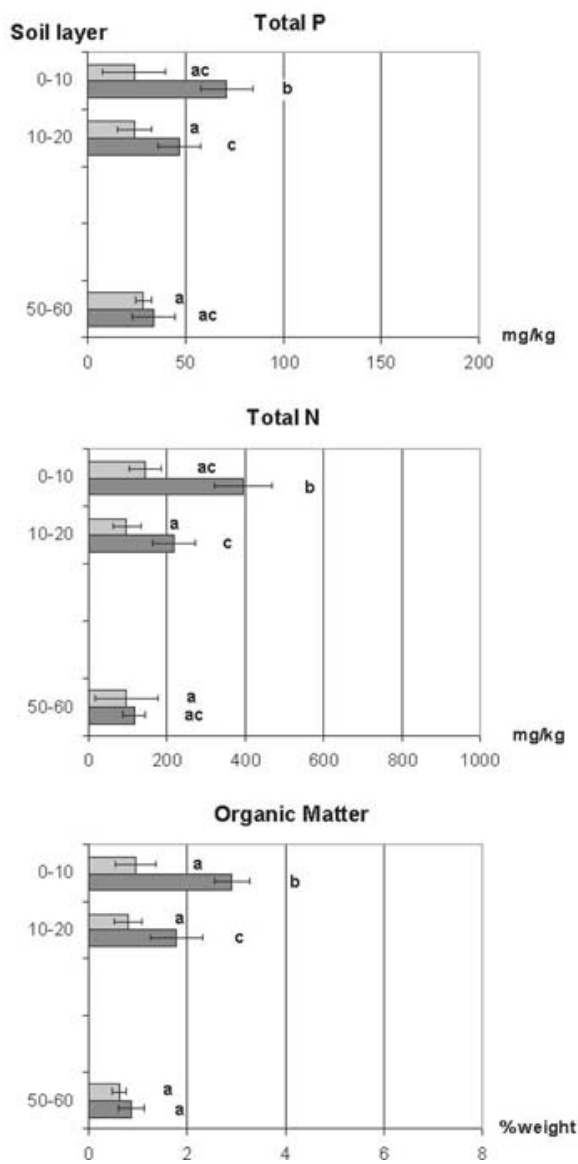

Table 5 Mean Ellenberg indicator values of the vegetation at the floodplains along the Beerze (Plot BH and BM) and the Snoeyinksbeek (Plot SH, SM and SL) in the summer of 2004 and 2005 (Ellenberg 1979)

\begin{tabular}{|c|c|c|c|c|c|c|c|c|c|}
\hline & \multicolumn{2}{|c|}{ Number of species } & \multirow[t]{2}{*}{ Found in both years } & \multicolumn{2}{|l|}{ Moist } & \multicolumn{2}{|l|}{ Acidity } & \multicolumn{2}{|l|}{ N-richness } \\
\hline & 2004 & 2005 & & 2004 & 2005 & 2004 & 2005 & 2004 & 2005 \\
\hline \multicolumn{10}{|c|}{ Snoeyinksbeek } \\
\hline Plot SH & 21 & 19 & 12 & $6.7 \pm 1.7$ & $6.2 \pm 1.6$ & $3.8 \pm 2.0$ & $4.6 \pm 2.3$ & $3.3 \pm 1.8$ & $4.4 \pm 2.1$ \\
\hline Plot SM & 29 & 25 & 14 & $7.3 \pm 1.4$ & $6.7 \pm 1.6$ & $4.1 \pm 2.2$ & $4.8 \pm 2.0$ & $3.8 \pm 2.2$ & $4.6 \pm 1.8$ \\
\hline Plot SL & 20 & 21 & 9 & $7.2 \pm 1.8$ & $7.1 \pm 1.4$ & $5.0 \pm 2.0$ & $5.5 \pm 1.6$ & $3.8 \pm 2.1$ & $5.1 \pm 1.6$ \\
\hline \multicolumn{10}{|l|}{ Beerze } \\
\hline Plot BH & 20 & 23 & 11 & $8.6 \pm 1.5$ & $8.7 \pm 1.5$ & $6.3 \pm 1.8$ & $6.3 \pm 1.1$ & $5.4 \pm 1.8$ & $6.2 \pm 1.9$ \\
\hline Plot BM & 11 & 15 & 10 & $8.9 \pm 1.1$ & $9.1 \pm 1.1$ & $6.0 \pm 1.5$ & $5.9 \pm 1.7$ & $5.4 \pm 1.9$ & $5.2 \pm 2.1$ \\
\hline
\end{tabular}

by three possible mechanisms, i.e., (1) infiltration of flood-water with a quite different water chemistry into the soil pores, (2) saturation of the soil pores and coverage of the soil with a water layer, thus inhibiting oxygen penetration into the soil and (3) sedimentation/ erosion phenomena in the upper centimeters of the soil. Our observations of pore water chemistry and soil nutrient changes as a result of flooding provide strong indications on the importance of these mechanisms. 
In the Beerze valley, our lithotrophic floodplain, the elevational gradient determined the pore water chemistry more strongly than the flooding event did, indicating that flooding had affected pore water chemistry only to a small extent. The hydrogeology of this floodplain, can be described as follows. The high water table caused by groundwater discharge is reflected in a water-saturated top soil layer in periods without flooding. Due to the water-saturation in the top layer, the flood-water did not infiltrate and the pore water chemistry did hardly react on the flooding event. The high water table prior to flooding and the well-buffered nature of the soil will have resulted in relatively minor changes in redox conditions and associated geochemical cycles.

On the contrary, in the atmotrophic floodplain at the Snoeyinksbeek, we found that flooding did affect pore water chemistry. However, the water chemistry data on flood-water and soil pore water showed that, again, the flood-water had hardly penetrated the soil pores. In this floodplain, the sandy soil had been welldrained and unsaturated prior to flooding. The rainfall just before and during flooding prevented the penetration of flood-water into the soil in the atmotrophic floodplain, and meanwhile drove the air out, thus substantially changing the redox conditions. In the lithotrophic Beerze situation, the changes during flooding remained remarkably insignificant. In the atmotrophic Snoeyinksbeek floodplain, the chemistry of the pore water indicated a rainwater influence after flooding, and further changes were probably due to increased anaeroby and associated redox changes of the soil.

The Soil $\mathrm{pH}$ tends to increase when soils become more reduced due to water-saturation, because of the consumption of free protons with reduction processes (Stumm and Morgan 1981; Langmuir 1997). No changes in $\mathrm{pH}$ occurred in response to flooding in the lithotrophic floodplain, whereas in the atmotrophic floodplain the $\mathrm{pH}$ did increase, accompanied with an increase of ammonium and some free basic cations, which indicates a lack of $\mathrm{pH}$ buffering capacity (Stumm and Morgan 1981; Langmuir 1997).

The top soil layers of the atmotrophic floodplain contained lower total nutrient contents than in the lithotrophic floodplain. Other investigators of seasonally flooded floodplains similar to ours (Kemmers et al. 2001; Runhaar and Jansen 2004), report values of total $\mathrm{N}>1,500 \mathrm{mg} / \mathrm{kg}$ and of total $\mathrm{P}>600 \mathrm{mg} /$ $\mathrm{kg}$, which is $5-8$ times higher than in the soils we studied, and organic matter contents of $11-25 \%$. This shows that both our floodplains have relatively low total nutrient contents. The low organic matter content in our floodplains may indicate the fairly young age of the soils, from which the original top layer had been removed only 3-4 years before our observations started. It is remarkable that flooding affected the organic matter and total $\mathrm{N}$ and $\mathrm{P}$ contents in the top soil in opposite ways in the two study sites: they increased in the atmotrophic floodplain of the Snoeyinksbeek, but decreased in the lithotrophic floodplain of the Beerze. Erosion and sedimentation during flooding could be responsible for these changes, but they were not measured. Organic material was possibly deposited after flooding in the small first-order Snoeyinksbeek subcatchment. The more turbulent regime in the much larger, deeply flooded Beerze stream has had a much more turbulent discharge at the onset of flooding and has probably eroded the nutrient-rich top layer of the soil. The decrease after flooding of bio-available $\mathrm{P}$ in the highest plot of the Beerze floodplain was probably associated with the decrease of organic matter and total $\mathrm{P}$ in the top soil.

The effects of flooding on plant site conditions were strongest in the atmotrophic floodplain, and vegetation responded accordingly. The disappearance or decline of Drosera intermedia, Calluna vulgaris, Luzula campestris and Ranunculus flammula may indicate the changed water regime in the atmotrophic floodplain, whereas at the same time the establishment and increase in abundance of Alopecurus pratensis, A. geniculatus, Sagina procumbens and Trifolium repens are indicative of the increase in nutrient availability in the floodplain. In the lithotrophic floodplain, the vegetation changes were small: we found a slight decline in abundance of Eleocharis acicularis, E. palustris and Lythrum salicaria, which were dominant in the first year. We should keep in mind that these floodplain sites are relatively young: 3 and 4 years after excavation for the atmotrophic and lithotrophic floodplain respectively. Therefore, vegetation changes may not have been caused by the effects of winter flooding alone.

Our study period covered one year of sampling in two study areas only, and it did not take account of their possibly different flooding histories. We can therefore not formulate very solid conclusions about 
the long-term effects of winter flooding. Most studies of the effects of flooding either extended over a much longer period of time (Mitsch et al. 2005; Carpenter 1998) or they included a larger number of floodplain sites (Narteh and Sahrawat 1999; Runhaar and Jansen 2004). Nevertheless, our elevational gradient approach yielded insights in the roles of characteristic gradients in soil aeration status and pore water chemistry.

Several studies have described the importance of groundwater influence in a floodplain. Van Dijk et al. (2004) found that $\mathrm{pH}$ buffering due to lithotrophic water in a rewetted floodplain overruled effects of reduction processes. Krebs et al. (1999) found that high groundwater levels lead to low N, P and K availability in shallow groundwater, because mineralization stops, $\mathrm{N}$ is depleted through denitrification and $\mathrm{P}$ is bound by calcium. Thus, the presence of a high water table seems to be important to maintain the original hydrochemistry in the soil. Van Diggelen et al. (1994) described disturbed brook valleys in their study; with top soil layers depleted of their former cation buffering capacity due to increased rainwater influence. They rather recommend concentrating the nature restoration on eutrophic marshes, where mesotrophic site conditions may be reached when the groundwater influence is restored. Grootjans et al. (2002) proposed to restore brook valley sites when groundwater influence is present, despite a eutrophic state.

Our study permits some general conclusions concerning the consequences of winter flooding for plant site conditions in lowland stream catchments. The effects of flooding are different for catchments of different size and stream order. However, our results suggest that, both in small, low-order subcatchments with atmotrophic pore water conditions and in larger subcatchments with lithotrophic pore water, the soil pores are hardly penetrated by the flood-water that always has a different water chemistry and high nutrient concentrations. The changes in water and soil chemistry occurring in the floodplains after flooding seem to be mostly caused by redox changes and by the deposition or removal of organic matter. The difference in stream order and size of the two streams may have an important role here. Shallow flooding of small, first-order streams may result in a net sedimentation of organic particles, while deep flooding of much larger streams in the lower basin may locally result in a loss of nutrient-rich organic top soil by erosion. The anaerobic conditions associated with flooding represent a more prominent change in well drained soils, which tend to provide atmotrophic rather than lithotrophic sites. Here, $\mathrm{pH}$, ammonium and phosphate levels will increase, when the soils become anaerobic.

Our results have shown that the plant species composition in winter-flooded sites does change in a direction that would be expected from the changes in wetness and in water and soil chemistry, even in a relatively short period of two years. These results suggest that originally atmotrophic and oligotrophic sites associated with low-order streams react more strongly to winter flooding than lithotrophic floodplains with groundwater discharge.

Acknowledgements We would like to show our gratitude to Vereniging Natuurmonumenten and Waterboard "Regge \& Dinkel" for permitting us entry to the areas and the supply of additional information. Further, we would like to thank Jorrit Schoen and Maaike Weijters for their help in the field and laboratory. We also thank the reviewer for the valuable comments on the manuscript.

\section{References}

Black AR (1995) Major flooding and increased flood frequency in Scotland since 1988. Phys Chem Earth 20(5-6):463468

Black AR, Werritty A (1997) Seasonality of flooding: a case study of North Britain. J Hydrol 195:1-25

Blom CWPM, Bogemann GM, Laan P, Vandersman AJM, Vandesteeg HM, Voesenek LACJ (1990) Adaptations to flooding in plants from river areas. Aquat Bot 38:29-47

Bray RH, Kurtz LT (1945) Determination of total, organic, and available forms of phosphorus in soils. Soil Sci 59:39-45

Bronstert A (1995) River flooding in Germany: influence by climate change? Phys Chem Earth 20(5-6):445-450

Burkett V, Kusler J (2000) Climate change: potential impacts and interactions in wetlands of the United States. J Am Water Resour Assoc 36:313-320

Caraco NF, Cole JJ, Likens GE (1989) Evidence for sulfatecontrolled phosphorus release from sediments of aquatic systems. Nature 341:316-318

Carpenter SR (1998) The need for large scale experiments to assess and predict the response of ecosystems to perturbation. In: Pace ML, Groffman PM (eds) Successes, limitations and frontiers in ecosystem science. SpringerVerlag, New York

De Louw P (2006) Wateratlas twente. De grond- en oppervlaktewatersystemen van Regge en Dinkel. Waterschap Regge en Dinkel, Almelo \& TNO Built, Environment and Geosciences, Utrecht 
DINO (2006) Netherlands Institute of Applied Geoscience TNO_National Geological Survey, Utrecht

Ellenberg H (1979) Zeigerwerte der Gefäszpflanzen Mitteleuropas. Scripta Geobotanica 9, Göttingen

Engelen GB, Gieske JMJ, Los SO (1989) Grondwaterstromingsstelsels in Nederland. SDU Uitgeverij, 's-Gravenhage

Everts FH, de Vries NPJ (1991) De vegetatieontwikkeling van beekdalsytemen. Historische Uitgeverij Groningen, Groningen

Gambrell RP, Wiesepape JB, Patrick WH, Duff MC (1991) The effects of $\mathrm{pH}$, redox, and salinity on metal release from a contaminated sediment. Water Air Soil Pollut 57(8):359-367

Grootjans AP (1985) Changes of groundwater regime in wet meadows. Dissertation, University of Groningen

Grootjans AP, Bakker JP, Jansen AJM, Kemmers RH (2002) Restoration of brook valley meadows in the Netherlands. Hydrobiologia 478:149-170

Hartig EK, Grozev O, Rosenzweig C (1997) Climate change, agriculture and wetlands in Eastern Europe: vulnerability, adaptation and policy. Clim Change 36:107-121

Houba VJG, van Schouwenburg JCH, Wallinga I, Novozamsky I (1995) Soil analysis II. Methods of analysis for soils. Wageningen University, Wageningen

Johnson WC, Millett BV, Gilmanov T, Voldseth RA, Guntenspergen GR, Naugle DE (2005) Vulnerability of northern prairie wetlands to climate change. Bioscience 55:863-872

Kemmers RH, Jansen PC, van Delft SPJ (2001) Waterbeheer en indirecte eutrofiering. Effecten op het Weidekervelgrasland (Sanguisorbo-Sileatum) in de Hengstpolder nabij Sliedrecht. Alterra-report 413, Wageningen

Kemmers RH, van Delft SPJ, Sival FP, Jansen PC (2003) Effecten van bevloeiing op de basen- en voedingstoestand van verzuurde en verdroogde beekdalgraslanden; Mogelijkheden van bevloeiing als effectgerichte maatregel. Alterra-report 748, Wageningen

Klein Tank AMG, Bessembinder JJF, van den Hurk BJJM, Lenderink G, van Ulden AP, van Oldenborgh GJ, Katsman CA, van den Brink HW, Keller F, Burgers G, Komen, Hazeleger W, Drijfhout SS (2006) Climate in the 21st century; four scenarios for the Netherlands. KNMI publication, The Netherlands

KNMI database (2005) Royal Netherlands Meteorological Institute, De Bilt http://www.knmi.nl/klimatologie/daggegevens/nsl-download.cgi. Cited: 12 Oct 2006

Kozerski HP (2003) Seston sedimentation in a lowland river (River Spree, Germany): their spatial and temporal variations and controlling factors. Hydrobiologia 494(13):51-55

Krebs L, Corbonnois J, Muller S (1999) The impact of hydrological fluctuations on shallow groundwater hydrochemistry under two alluvial meadows. Hydrobiologia 410:195-206

Lamers LPM, Tomassen HBM, Roelofs JGM (1998) Sulfateinduced eutrophication and phytotoxicity in freshwater wetlands. Environ Sci Technol 32:199-205

Langmuir D (1997) Aqueous environmental geochemistry. Prentice-Hall, New Jersey
Maucha R (1932) Hydrochemische methoden in der limnologie. Die Binnengewässer, Stuttgart

McCarthy JJ, Canziani OF, Leary NA, Dokken DJ, White KS (eds) (2001) Climate change 2001: impacts, adaptation \& vulnerability. Cambridge University Press, UK

Ministry of Housing, Spatial Planning and the Environment (2001) Fifth National Policy Document on Spatial Planning 2000/2020

Mitsch WJ, Zhang L, Anderson CJ, Altor AE, Hernandez ME (2005) Creating riverine wetlands: ecological succession, nutrient retention, and pulsing effects. Ecol Eng 25:510527

Mortsch LD (1998) Assessing the impact of climate change on the Great Lakes shoreline wetlands. Clim Change 40:391416

Narteh LT, Sahrawat KL (1999) Influence of flooding on electrochemical and chemical properties of West African soils. Geoderma 87:179-207

Parkhurst DL, Appelo CAJ (1999) User's guide to PHREEQC (version 2)-A computer program for speciation, batch-reaction, one-dimensional transport, and inverse geochemical calculations. US Geol. Survey, Water resource. Inv. Rep, pp 99-4259

Reddy KR, Kadlec RH, Flaig E, Gale PM (1999) Phosphorus retention in streams and wetlands: a review. Crit Rev Environ Sci Technol 29:83-146

Runhaar J, Jansen PC (2004) Overstroming en vegetatie. Vergelijkend onderzoek in vijf beekdallocaties. Alterrareport, Wageningen

Stortelder AHF, Hommel PWFM, de Waal RW, van Dort KW, Vrielink JG, Wolf RJAM (1998) Broekbossen. KNNV Uitgeverij, Utrecht

Stumm W, Morgan JJ (1981) Aquatic chemistry: an introduction emphasizing chemical equilibria in natural waters. New York

Stuurman R, Beusekom G, Reckman J (2000) Watersystemen in Beeld. Een beschrijving en kaarten van de grond- en oppervlaktewatersystemen van Noord-Brabant. TNO-report NITG 00-10-A

Troelstra SR, Wagenaar R, de Boer W (1990) Nitrification in Dutch Heathland Soils .1. General soil characteristics and nitrification in undisturbed soil cores. Plant Soil 127(2): 179-192

Van Diggelen R, Grootjans AP, Burkunk R (1994) Assessing restoration perspectives of disturbed brook valleys: the Gorecht area, the Netherlands. Restor Ecol 2:87-96

Van Dijk J, Stroetenga M, Bos L, Van Bodegom PM, Verhoef HA, Aerts R (2004) Restoring natural seepage conditions on former agricultural grasslands does not lead to reduction of organic matter decomposition and soil nutrient dynamics. Biogeochemistry 71:317-337

Van Wirdum G (1991) Vegetation and hydrology of floating rich-fens. Dissertation, University of Amsterdam

Visser EJW, Voesenek LACJ, Vartapetian BB, Jackson MB (2003) Flooding and plant growth. Ann Bot 91:107-109

Walls RP, Wardop DH, Brooks RP (2005) The impact of experimental sedimentation and flooding on the growth and germination of floodplain trees. Plant Ecol 176(2):203-213 
Wassen MJ (1995) Nutrient concentrations in Mire vegetation as a measure of nutrient limitation in Mire ecosystems. J Veg Sci 6(4):608-608

Wassink WTh (1999) Beekdallandschappen. Een morfologisch onderzoek in de zandgebieden van Nederland. Dissertation, Wageningen University
Watson RT and the Core Writing Team (eds) (2001) Climate change 2001: synthesis report. IPCC, Geneva

Winter TC (2000) The vulnerability of wetlands to climate change: a hydrologic landscape perspective. J Am Water Resour Assoc 36:305-311 